\title{
Intuitive Toxicology II: Expert and Lay Judgments of Chemical Risks in Canada
}

Paul Slovic, ${ }^{\mathrm{a}}$ Torbjorn Malmfors, ${ }^{\mathrm{b}}$ Daniel Krewski, ${ }^{\mathrm{c}}$ C.K. Mertz, ${ }^{\mathrm{a}}$ Nancy Neil, ${ }^{\mathrm{d}}$ and Sheryl Bartlett ${ }^{\mathrm{c}}$

${ }^{a}$ Decision Research, 1201 Oak Street, Eugene, Oregon 97401-3575

${ }^{b}$ Malmfors Consulting, AB, Vastmannagatan 48, S-113 25 Stockholm, Sweden ${ }^{c}$ Health Canada, Ottawa

d(formerly Nancy Kraus) School of Pharmacy SC-69, University of Washington, Seattle, Washington 98195

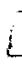

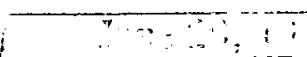

Risk Analysis, in press. 


\begin{abstract}
This study is a replication and extension in Canada of a previous study in the United States in which toxicologists and members of the public were surveyed to determine their attitudes, beliefs, and perceptions regarding risks from chemicals. This study of "intuitive vs. scientific toxicology" was motivated by the premise that different assumptions, conceptions, and values underlie much of the discrepancy between expert and lay views of chemical risks. The results showed that Canadian toxicologists had far lower perceptions of risk and more favorable attitudes toward chemicals than did the Canadian public. The public's attitudes were quite negative and showed the same lack of dose-response sensitivity found in the earlier U.S. study. Both the public and the toxicologists lacked confidence in the value of animal studies for predicting human health risks. However, the public had great confidence in the validity of animal studies that found evidence of carcinogenicity, whereas such evidence was not considered highly predictive of human health risk by many toxicologists. Technical judgments of toxicologists were found to be associated with factors such as affiliation, gender, and worldviews. Implications of these data for risk communication are briefly discussed.
\end{abstract}

Key words: Intuitive toxicology, Risk perception, Chemical risks, Expert judgment, Risk communication 


\section{Introduction}

This study is a replication and extension in Canada of an earlier study by Kraus, Malmfors, and Slovic ${ }^{(1)}$ in which members of the U.S. Society of Toxicology and members of the general public in Portland, Oregon, were surveyed to determine their attitudes, beliefs, and perceptions regarding risks from chemicals.

The study by Kraus et al. was motivated by the premise that different assumptions, conceptions, and values underlie much of the discrepancy between expert and lay views of chemical risks. They attempted to address this issue by exploring the cognitive models, assumptions, and inference methods that comprise laypeople's "intuitive toxicological theories" and by comparing these theories with the cognitive models, assumptions, and inference methods of scientists working in the field of toxicology.

Toxicologists and laypeople were found to differ greatly, documenting some common assumptions (e.g., that the public believes natural chemicals to be safer than synthetic ones) and verifying many of the other hypotheses that motivated the questionnaire. Of particular importance was the finding that the public is much less sensitive than the experts to considerations of dose and exposure. Lay respondents generally tended to view chemicals as either safe or dangerous, and they appeared to equate even small exposures to toxic or carcinogenic chemicals with almost certain harm. This tendency was found to be associated with high levels of concern about very small residues of chemicals on food and with a desire to reduce chemical risks regardless of cost. Although Kraus et al. were not able to develop a precise description of the lay mental models of how a chemical carcinogen works, their results 
were consistent with a contagion or contamination model, ${ }^{(2)}$ which is obviously very different from the kinds of models that toxicologists hold.

One of the major surprises in the data was the lack of difference between the public and toxicologists with regard to their confidence in extrapolation from animal studies. Both groups were divided in their opinions, and the high percentage of experts who lacked confidence in animal studies is particularly noteworthy in light of the extensive reliance on such studies in risk management. Also, whereas the public's trust in extrapolation from animal studies increased greatly when these studies were found to produce evidence of carcinogenicity, toxicologists became less confident that such evidence could be used to predict cancer risk in humans. Kraus et al. also found an affiliation bias; toxicologists working for industry saw chemicals as more benign than did their counterparts in academia and government.

The present study provides a partial replication of the work by Kraus et al. to determine whether the results from members of the U.S. Society of Toxicology would apply to toxicologists in Canada and to determine whether results from one American city, Portland, Oregon, would apply to a representative national sample of the Canadian population. Whereas Kraus et al. used the identical survey for toxicologists and laypersons, the present study used two similar but not identical surveys. The primary difference was that the toxicologists' surveys included several highly technical questions inappropriate for the lay public.

A detailed report of the public survey in Canada has been provided elsewhere. ${ }^{(3-5)}$ The present report will focus on the data from the survey of Canadian toxicologists with selected comparisons being made to the survey of the Canadian public. : 
Intuitive Toxicology II $\bullet$ page 5

\section{Method}

\subsection{Survey Content}

The survey administered to toxicologists addressed many different aspects of health-risk assessment. Accordingly, a variety of question types and formats were used, including ratings of perceived risk, attitude and opinion questions, and questions pertaining to the technical evaluation of several chemicals. The main components of the survey are outlined below. ${ }^{1}$

Risk perception. In the first segment of the survey, respondents were asked to indicate the degree of health risk they associated with each of 33 hazards. These 33 items covered a wide range of hazards, including risks from technology (e.g., nuclear power, high-voltage power lines), lifestyle (e.g., AIDS, drinking alcoholic beverages, cigarette smoke), pollution (e.g., waste incinerators, indoor air quality), common substances (e.g., bacteria in food, tap water), and crime and violent behavior. The array of items was selected to include many of the hazards that had recently been of concern to the public, the medical community, and government agencies.

Each of these items was rated in terms of the health risk posed "to the Canadian public as a whole." The possible responses were "almost no health risk," "slight health risk," "moderate health risk," and "high health risk." In addition, for 10 of the items thought to pose risks to respondents and their families that might be quite different from the risks to the

\footnotetext{
${ }^{1} \mathrm{~A}$ copy of the survey is available from the first author.
} 
general public (e.g., street drugs), ratings were also obtained for "the health risk to you and your family."

Five additional items, representing medical devices or treatments, were rated on perceived health risk under the assumption that "you or some member of your family were considering using the following medical devices or treatments." These five items included breast implants, medical $\mathrm{X}$ rays, contraceptives, contact lenses, and heart pacemakers.

Responsibility for health-risk protection. A diverse set of private individuals, private groups, and government agencies were rated according to the degree of responsibility they were perceived to have for protecting people against health risks. These same individuals and groups were also rated according to how good a job each was doing in fulfilling their responsibilities for protecting people against health risks.

Attitudes and opinions. The middle segment of the survey contained 22 items designed to elicit the respondents' attitudes and opinions regarding a variety of health-risk perception issues. These items were presented as statements with which the respondent was asked to agree or disagree. The content of these items included statements about (a) one's local environment ("There are serious environmental health problems where I live"); (b) attitudes toward government regulation (e.g., "When there is a serious health problem, the government will regulate it. Until they alert me..., I don't really have to worry"); (c) risk/benefit tradeoffs (e.g., "Canadians should be prepared to accept some risks to their health in order to strengthen the economy"); and (d) judgments about risks from chemicals and radiation. 
Intuitive Toxicology II $\bullet$ page 7

Worldviews. Over the past decade, evidence has been accumulating regarding the importance of general dispositions or "worldviews" in determining an individual's perceptions of risk. ${ }^{(6-8)}$ The survey contained a small number of statements designed to determine agreement or disagreement with the following worldviews: (a) fatalism/control (e.g., "I feel I have very little control over risks to my health); (b) hierarchy ("Decisions about health risks should be left to the experts" and "People in positions of authority tend to abuse their power"); (c) individualism ("In a fair system, people with more ability should earn more" and “Government has no right to regulate people's personal risk-taking activities such as smoking, mountain climbing, etc."); (d) egalitarianism ("If people in this country were treated more equally, we would have fewer problems"); (e) technological enthusiasm ("A high technology society is important for improving our health and social well-being"); (f) economic growth ("Continued economic growth is necessary to improve our quality of life"); and (g) consent ("When a risk is very small, it is OK for society to impose that risk on individuals without their consent"):

Toxicological evaluations. Two series of questions were directed toward technical judgments of specific chemicals. In the first series, a table was presented summarizing the two-year study of Bromoethane done within the National Toxicology Program (NTP). The standard NTP protocol was used, in which four separate studies were conducted, one each with male mice, female mice, male rats, and female rats. The summary of results from these four studies was presented in the survey in the form of a summary table. Bromoethane is an alkylating agent used primarily as a chemical intermediate in various organic syntheses. The 
chemical was identified only as "Chemical B" in the survey. Respondents were asked to study the summary table and, for each study, judge the level of carcinogenic activity of Chemical B for male rats, female rats, and so on according to the NTP criteria, which were also defined and displayed in the survey. The NTP categories were: clear evidence of carcinogenic activity, some evidence, equivocal evidence, no evidence, and inadequate evidence. Respondents were also asked whether they agreed or disagreed that "In general animal studies of the type done with Chemical B will permit one to make reliable judgments of the likelihood that the chemical is carcinogenic in humans," and "Based on the data presented above (in the table), a concentration of $1 \mathrm{ppb}$ of Chemical B in indoor air is acceptable." Finally, they were asked to indicate whether Chemical B is carcinogenic in humans.

Next, respondents were shown the following paragraph describing results of studies done on the chemical 2-mercaptobenzothiazole, labeled in the survey as "Compound E."

$\mathrm{E}$ is used as a rubber accelerant and a preservative. The annual production is several million kilograms. It is a solid material with a disagreeable odor. It is insoluble in water but soluble in different solvents. It occurs as a contamination in medicinal products and in rubber baby bottle nipples. It inhibits dopamine-B-hydroxylase.

$\mathrm{E}$ has a low acute toxicity $\left(\mathrm{LD}_{50}\right.$ in rats is $2-3 \mathrm{~g} / \mathrm{kg}$ given orally). At repeated oral administration hepatomegaly and forestomach lesions are found in rats at doses around $500 \mathrm{mg} / \mathrm{kg}$. A reproductive toxicity study did not show any toxic effects at $200 \mathrm{mg} / \mathrm{kg}$ given intraperitoneal day 1-15 gestation including embryotoxicy, which was indicated in another study. Genotoxic effects were found in mammalian cells but not in bacteria.

Carcinogenicity studies were evaluated as showing some evidence of carcinogenic activity in rats-mononuclear cell leukemia, pancreatic acinar cell adenomas, adrenal gland pheochromocytomas, and pituitary gland adenomas in females. In mice there was no evidence in males and equivocal evidence in females-hepatocellular adenomas or carcinomas-at $750 \mathrm{mg} / \mathrm{kg}$ given by gavage. 
Intuitive Toxicology II $\bullet$ page 9

$\mathrm{E}$ has been shown to be a very strong allergen in guinea pigs but is judged a moderate contact sensitizer in humans.

Respondents were asked to judge the relative toxicity of Chemical E, the risk of using it as a rubber accelerant and preservative, the factors they took into account in assessing its toxicity, and the acceptability of using it in rubber nipples for baby bottles.

Chemicals B and E were selected because animal data raised a number of questions that made the interpretations and evaluations "nonobvious."

Personal characteristics and professional experience. The final section of the survey elicited information pertaining to the personal and professional background of the respondent.

The survey administered to the lay public was similar except it did not include the technical questions and the survey of professional experience, and it included several risk perception items not given to the toxicologists:

\subsection{Administration of the Survey}

The survey was mailed to all 490 members of the Canadian Society of Toxicology in March of 1993. There were 150 completed surveys returned for a response rate of $30.6 \%$.

The survey of the general public was conducted by Goldfarb Consultants. A representative sample of the Canadian adult population was interviewed by telephone. The interviewing was conducted in either English or French between February 14 and February 24, 1992. A stratified random sampling procedure produced 2765 contacts from which 1506 completed interviews were obtained, for a response rate of $54.5 \%$. 


\section{Results}

\subsection{Background Characteristics}

About half of the toxicologists who completed the survey were age 44 or younger; $76.7 \%$ were male; $70.7 \%$ had a Ph.D. or M.D. degree. Biology was the most common academic background $(38.7 \%)$ followed by chemistry $(14.7 \%)$ and medicine $(14.7 \%)$. Some $40 \%$ were primarily affiliated with academic institutions; $16.0 \%$ with a government regulatory agency, and $14.0 \%$ with private industry. Their main (current) position varied among applied research (23.3\%), basic research $(21.5 \%)$, administration $(18.4 \%)$, teaching $(15.4 \%)$, and regulation (9.4\%). Most (58.0\%) said that general toxicology was their primary field. In terms of primary experience, $49.3 \%$ had worked frequently with drugs, $41.3 \%$ had worked frequently with experimental toxicants, $35.3 \%$ with industrial chemicals, $32.7 \%$ with chemical pollutants, $22.7 \%$ with pesticides, and only a few had worked frequently with food additives $(6.0 \%)$ and cosmetics $(2.7 \%)$. Whereas $66.0 \%$ engaged frequently in research, $44.7 \%$ frequently did toxicological evaluation, and $26.7 \%$ frequently did risk assessment. The major test system used by these people was animal studies $(66.0 \%$ frequently worked with these systems) compared to $36.0 \%$ (worked frequently with in vitro systems) and $20.0 \%$ (worked frequently with humans). Survey respondents were highly experienced (58.7\% had more than 10 years' experience in experimental work and $42.7 \%$ had similar length of experience in evaluation of chemicals). 


\subsection{Ratings of Risk}

Figure 1 presents the response distributions for the toxicologists' judgments of health risk to the Canadian public as a whole. ${ }^{2}$ Cigarette smoking and motor vehicle accidents had, by far, the highest ratings of risk. Other lifestyle and behavioral risks such as stress, alcohol, crime, suntanning, breast implants, street drugs, and AIDS were rated next highest. The remaining items, including most of the chemical hazards, were rated rather low in risk, the exception being ozone depletion.

Insert Figure 1 about here

Figure 1 can be compared with the ratings in the survey of the Canadian public in Figure $2{ }^{(5)}$ Smoking again tops the list but not by as large a margin as in the survey of toxicologists. Ozone depletion is second, higher ranked than in the toxicologists' survey, and motor vehicle accidents were lower ranked by the public. Members of the public were more likely than toxicologists to label an item a "high risk" for 36 of the 38 items, and the discrepancy was often quite large. Similar discrepancies existed when the public and the toxicologists rated health risks to "you and your family" rather than to the Canadian public as a whole.

Insert Figure 2 about here

\footnotetext{
${ }^{2}$ Included in the figure are the five items for which the rated risk pertained to an individual considering the use of a specific medical device or treatment. These items were breast implants, medical X rays, contraceptives, contact lenses, and heart pacemakers.
} 
Figure 3 compares the proportion of moderate risk and high risk ratings of men and women toxicologists. The women tended to rate an item moderate or high in risk more frequently than the men, similar to the way that women and men in the general public respond. The "gender gap" was particularly large for asbestos and breast implants, followed by chemical pollution, nuclear waste, ozone depletion, and alcohol and pregnancy.

\section{Insert Figure 3 about here}

\subsection{Responsibility for Protecting Against Health Risks}

The toxicologists believed that individual citizens were most responsible for protecting against health risks, followed by Health and Welfare Canada. Health and Welfare Canada was seen as doing the best job in fulfilling that responsibility (though few responses were in the "excellent" category); citizens and private industry were judged poorest at fulfilling this responsibility. These data contrast with views of the general public who saw medical doctors and other health professionals rather than citizens and government as most responsible.

Differences between the public's and the toxicologists' ratings of performance in meeting these responsibilities were small.

\subsection{Attitudes and Opinions}

Tables 1 to 8 present the toxicologists' response distributions for the 30 attitude and opinion statements. These statements have been grouped by content category for easier interpretation.

Category 1 (Table 1) includes general statements regarding the risks from exposure to chemicals. A strong majority of toxicologists (82.6\%) agreed that the use of chemicals has 
improved our health more than it has harmed it (Statement 1a) and disagreed $(90.0 \%)$ that most chemicals cause cancer (Statement 1b). About 30\% agreed that they try hard to avoid contact with chemicals and chemical products in their daily life, a surprising response that warrants further study.

Insert Table 1 about here

Category 2 (Table 2) included two questions designed to gauge one's trust in the use of animal studies to determine a chemical's risk to humans. There was substantial agreement $(66.0 \%)$ with the general Statement $2 a$, "The way that an animal reacts to a chemical is a reliable predictor of how a human would react to it." However, when an animal study was said to provide "evidence that a chemical causes cancer in animals" (Statement 2b), agreement that it "will cause cancer in humans" decreased to $51.3 \%$. The Canadian public showed the opposite pattern of response, with $60.3 \%$ agreeing on Statement $2 \mathrm{a}$ and $82.3 \%$ agreeing with $2 b$. Thus, whereas animal studies that find evidence of cancer are highly credible and ominous for the public, toxicologists are quite divided regarding the implications of these studies for human health.

Insert Table 2 about here

Attitudes toward regulation of chemical hazards are indicated by responses to statements in Category 3 (Table 3). The picture is mixed. Moderate confidence in the regulatory system is shown by the $49.4 \%$ of respondents who agreed that "Chemical risks are 
adequately regulated" (Statement 3a). However, there was $82 \%$ disagreement with Statement $3 b$ that government regulation permits one the luxury of not having to worry about serious health problems, and $80 \%$ disagreement with the statement that "Because chemicals provide many benefits...there should be less regulation..." (Statement 3c). There was only $22.7 \%$ agreement with the statement that "A prescription drug that hasn't been formally tested but has been used for 20 years is safer than a new prescription drug that has been tested and approved for use under the present guidelines" (Statement 3d). Support for the general principle of regulatory intervention was shown by the tendency to disagree $(71.3 \%)$ with the statement that government has no right to regulate people's personal risk-taking (Statement 3e).

Insert Table 3 about here

Statements $4 a$ and $4 c$ in Category 4 (Table 4 ) assessed the respondents' sensitivity to the relationship between dose or amount of exposure to a chemical and the degree of health risk. Whereas the public tended to equate any degree of exposure with harm, the toxicologists viewed things quite differently; $83 \%$ disagreed with Statement $4 \mathrm{a}$ asserting that exposure to a carcinogen implies that the exposed person will probably get cancer some day, and $74.6 \%$ disagreed with Statement $4 \mathrm{c}$ asserting that if even a tiny amount of a carcinogen "were found in my tap water, I wouldn't drink it." Toxicologists also rejected the view of chemicals as either safe or dangerous ( $94 \%$ disagreement with Statement $4 \mathrm{~b})$. 
Three additional statements about cancer are grouped in Category 5 (Table 5). Responses to Statement 5a (83.3\% agreement) indicate that most toxicologists share the view presented by Ames $^{(10)}$ that fruits and vegetables contain natural substances that are carcinogenic. Most of the toxicologists $(66 \%)$ also agreed that "people worry too much about getting cancer from exposure to chemicals." Most (84.6\%) also agreed that lifestyle factors such as smoking and diet posed much greater cancer risks than did chemicals in the environment.

Insert Table 5 about here

Six miscellaneous questions are contained in Category 6 (Table 6). Statement-6a

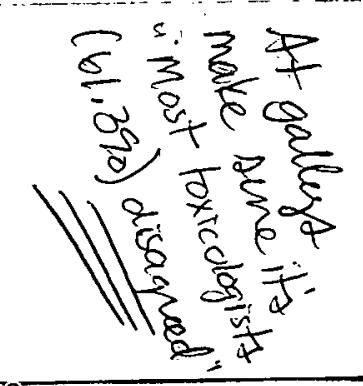
indicates that $84 \%$ disagreed ( $54 \%$ strongly so) with the assertion that natural chemicals are not as harmful as man-made chemicals, in contrast to the view forcefully proposed by Rachel Carson in Silent Spring. ${ }^{(11)}$ Most of the Canadian public, however, still sides with the Carson position (38.2\% disagreed with $6 \mathrm{a} ; 56.1 \%$ agreed). Only $23.3 \%$ of the toxicologists agreed that "there are serious environmental health problems were I live" (Statement 6b). Almost two-thirds $(62.6 \%)$ of toxicologists agreed that people can offset pollution risks by improving their lifestyles (Statement 6c), and only $20 \%$ agreed that a risk-free environment is an attainable goal (Statement 6d). Most toxicologists (61.3\%) disagreed that Canadians should $c^{1}$ accept some health risks in order to strengthen the economy (Statement 6e). Finally, only $43.4 \%$ of toxicologists agreed that experts are able to make accurate estimates of health risks from chemicals in the environment (Statement 6f); 53.3\% disagreed. 
Insert Table 6 about here

\subsection{Worldviews}

Response distributions for questions pertaining to worldviews (also known as orienting dispositions) are shown as Category 7 in Table 7. Most respondents (65.3\%) disagreed with the fatalistic view in Statement 7a to the effect that they had little control over risks to their health. Two statements reflecting adherence to hierarchial forms of social organization found relatively weak support. In $7 \mathrm{~b}$, only $31.3 \%$ agreed that decisions about health risks should be left to the experts. In $7 \mathrm{c}$, only $42.7 \%$ disagreed that people in positions of authority tend to abuse their power. The individualistic statement that people with more ability should earn more (Statement $7 \mathrm{~d}$ ) was supported by $82.6 \%$ of the respondents. Egalitarianism, as expressed in Statement 7e, received mixed response (34.7\% agreement; $51.7 \%$ disagreement), and there was substantial agreement $(72.7 \%)$ with the notion that a high technology society is important for improving health and well-being (Statement 7f). About one-third (33.4\%) agreed that when a risk is very small, it is $\mathrm{OK}$ for society to impose that risk on individuals without their consent (Statement $7 \mathrm{~g}$ ), and a majority (60.7\%) agreed that continued economic growth is necessary to improve our quality of life. 


\subsection{Attitudes, Opinions, and Worldviews: Comparisons With the Canadian Public}

Just as risk judgments differed greatly between members of the Canadian public and toxicologists, so did many attitudes, opinions, and worldviews. Figure 4 compares the percent agreement for toxicologists and the public across the 26 statements given in both surveys. The discrepancy in agreement exceeded $20 \%$ for 17 of the 26 items. The public showed much less sensitivity to degree of exposure or to degree of risk (statements $4 c, 4 a$, and $4 b$ ) and much more negative attitudes toward chemicals (statements $1 \mathrm{c}, 1 \mathrm{~b}$, and $1 \mathrm{a}$ ). These negative attitudes are consistent with a public view that sees danger even in small exposures to chemicals. As noted earlier, the public was much more likely to agree that natural chemicals are less harmful than man-made chemicals (Statement 6a) and to disagree that fruits and vegetables contain natural substances that can cause cancer (Statement 5a). The public agreed more with the egalitarian (Statement 7c) and fatalism (Statement 7a) views and were more inclined to distrust people in positions of authority (Statement 7c). Also, as noted earlier, members of the public were more likely to see positive evidence of carcinogenicity in animal studies as implying danger to humans (Statement $2 b$ ).

Insert Figure 4 about here

\subsection{Attitudes and Opinions: Gender Effects Between Men and Women Toxicologists}

Among toxicologists, men were more likely than women to agree that people in positions of authority tend to abuse their power, that decisions about health risks should be left to the experts, that people with more ability should earn more money, and that a high technology 
Intuitive Toxicology $I I \bullet$ page 18

society is important for improving health and social well-being. Although women were somewhat more likely to agree that economic growth is necessary to improve quality of life, men were more likely to agree that Canadians should accept some risks in order to strengthen the economy. Men were also more likely to endorse the view that use of chemicals has improved our health more than it has harmed it and to assert that a risk-free environment is possible in Canada. Other differences in agreement percentages between men and women were rather small (less than $10 \%$ ).

\subsection{The Risk-Perception Index}

There was a moderately strong tendency for toxicologists to be consistent across hazards in their ratings of risk. Ratings for $96 \%$ of the 703 pairs among the 38 hazards studied here were positively correlated across respondents (the mean and median of the distribution of these correlations were .24 and .22 , respectively). Thus, for example, the rated risk to the public from nuclear power plants correlated .50 with rated risk from chemical pollution. Judged risk from nuclear power also correlated highly (.32) with perception of a very different type of risk-street drugs.

A risk-perception index was created for each respondent by averaging his or her ratings across all 38 hazard items. These index values were correlated with responses to the attitude, opinion, and worldview statements presented in Tables 1 to 7 . These correlations are shown in parentheses next to each question in Tables 1 to 7 . We can see that the risk-perception index was significantly correlated with at least one statement from every category. In general, high correlations were found for items in Category 1 (Table 1; general opinions) and Category 4 
(Table 4; relationship between exposure and risk). Persons with generally negative attitudes toward chemicals and with less sensitivity to dose-response relationships tended to have higher average ratings of risk across the 38 items. In Table 1, for example, the index correlated .44 with the view that "most chemicals cause cancer" (Statement 1b). Toxicologists with high average risk ratings tended to disagree that risks are adequately regulated (statements $3 \mathrm{a}$ and 3b) and disagree that people worry too much about getting cancer from exposure to chemicals (Statement $5 b$ ). They tended to agree that natural chemicals are not as harmful as man-made chemicals (Statement 6a), and to agree with the antihierarchal view and egalitarian view expressed in statements $7 \mathrm{c}$ and $7 \mathrm{e}$. They also tended to disagree that small risks should be imposed on people (Statement $7 \mathrm{~g}$ ). In general, the way that the risk perception index related to the various attitudes and opinions of toxicologists was quite similar to the way the index related to the views of the general public (the pattern of correlations in the two studies correlated .84 across the 26 statements common to both the toxicologist survey and the public survey).

\subsection{Technical Evaluations}

A special feature of this survey was the inclusion of two sets of technical evaluations for Chemical B and Compound E. The response distributions for questions about Chemical B are shown in Table 9. There is substantial disagreement among the respondents in the interpretation of the animal studies, particularly for male and female rats. The percentage of those surveyed whose responses agreed with that of the majority in the NTP panel ranged from 
Intuitive Toxicology II $\bullet$ page 20

$56 \%$ for female mice to $22 \%$ for male rats. Only eight persons $(5.7 \%)$ matched the NTP panel on all four studies.

Insert Table 9 about here

There was also disagreement about whether animal studies of this type permit reliable extrapolation to human cancer risks (Statement B5). Only 50.6\% agreed that reliable extrapolation is possible and $38 \%$ disagreed. Despite these concerns, about $59 \%$ rated Chemical B as a probable or possible carcinogen in humans (Statement B7), and $52.7 \%$ agreed that $1 \mathrm{ppb}$ of the chemical in indoor air would be acceptable.

Evaluations of Compound $\mathrm{E}$ are shown in Table 10. Most respondents (74.7\%) judged its toxicity to be in the low to moderate range and most $(68.7 \%)$ judged its risk similarly (low to moderate). Respondents were divided about the acceptability of Compound $\mathrm{E}$ in rubber baby bottle nipples ( $48.7 \%$ disagreed that it was acceptable; $24.6 \%$ agreed that it was acceptable; $26.7 \%$ didn't know or had no opinion).

Insert Table 10 about here

The risk-perception index described earlier was found to correlate significantly $(r=$ -.16) with the evaluation of Chemical B in the study of male rats (those with higher risk ratings were more likely to judge Chemical B as showing some or clear evidence of carcinogenicity); with the acceptability of Chemical B in indoor air ( $r=-.24$, item B6); with 
the evaluation of Chemical B as a probable human carcinogen $(r=.19)$; and with the judgments of toxicity and risk of Compound $\mathrm{E}(r=.24$ and .20 , respectively).

Each respondent was given a score (called the pattern index) based on his or her evaluations of the four studies with Chemical B (items B1 to B4). A response of clear evidence or some evidence was coded as 1 ; equivocal evidence as 2 ; and no or inadequate evidence as 3. These values were summed over the four responses. A low score on the index indicated a tendency to see strong evidence for carcinogenicity in each of the four studies. This index was correlated with the individual item ratings of risk for the 38 hazards and with the attitudes and opinions expressed in the rest of the survey. A stepwise multiple regression analysis found four statistically significant predictors of the pattern index, leading to $R=.40$. According to these predictors, an overall tendency to judge Chemical B as carcinogenic across all four NTP studies was correlated with seeing a high risk in another chemical (E), with disagreeing that figures in authority abuse power; with being female; and with seeing high risk to society from nuclear power plants.

\subsection{Affiliation Effects}

One of the more intriguing findings in the study by Kraus et al. ${ }^{(1)}$. was that toxicologists in industry were somewhat less inclined than other toxicologists to agree that a study producing evidence that a chemical causes cancer in animals indicates that we can be reasonably sure that the chemical will cause cancer in humans. Only $22 \%$ of toxicologists working in industry endorsed this view, compared to $48.9 \%$ and $52.7 \%$ endorsement among academics and government employees. This tendency was replicated in the present study, though the 
discrepancy was smaller. Whereas $42.1 \%$ of those in industry endorsed this statement, $58.3 \%$ and $56.4 \%$ of the academics and government employees endorsed it. There was little difference in response to the general statement (2a) about animal testing ("The way that an animal reacts to a chemical is a reliable predictor of how a human would react to it"), with $71.7 \%$ of academics, $68.4 \%$ of government employees, and $68.2 \%$ of industry employees agreeing. The affiliation difference only appeared once the study was said to have found evidence for cancer. This also replicates the pattern of results obtained by Kraus et al..$^{(1)}$

Although there were other risk judgments and opinion statements that were correlated with affiliation, these differences are difficult to interpret and will not be discussed here in detail. The sample sizes were small (only between 37 and 60 persons in each category) and the background questionnaire found affiliation to be correlated with a number of other facets of experience. For example, academics spent more time doing research than did toxicologists in government and industry. Academics also worked more with in vitro and animal systems and less with humans, and they were less experienced in doing risk assessment. Those in industry had more experience working with humans and doing product testing, and they were also more involved than the others in risk-management issues. In sum, reliable affiliation effects exist, but sorting out the underlying causes from among the wealth of confounding factors will take additional research focused specifically on this task.

\section{Discussion}

The present study of toxicologists in Canada, contrasted with the data from the survey of the Canadian pubic ${ }^{(3-5)}$ replicates and extends the results obtained in the United States. ${ }^{(1)}$ Canadian 
toxicologists had far lower perceptions of risk for all hazards and more favorable attitudes toward chemicals than did the Canadian public. The public's attitudes toward chemicals were quite negative and showed the same lack of dose-response sensitivity found in the U.S. study. Both the public and the toxicologists exhibited a lack of confidence in the value of animal studies for predicting human health risks. An important result, also found in the U.S., was that a study showing evidence that a chemical caused cancer in animals led to high confidence within the public that the chemical would cause cancer in humans but did not elicit great confidence among the toxicologists. Affiliation effects found in the U.S. survey were replicated in the Canadian survey of toxicologists but must be interpreted cautiously because of the confounding of affiliation with other aspects of background and experience.

A special feature of the present survey was the inclusion of technical material for the toxicologists to evaluate and the inclusion of questions pertaining to worldviews. The range of disagreement on some of the technical questions was significant as was the correlation between technical judgments and some "nonscientific" factors such as gender and worldviews. Also important was the lack of agreement that animal studies of the type done in the NTP program will permit reliable judgments of a chemical's carcinogenic potential in humans.

Kraus et al. ${ }^{(1)}$ presented a lengthy discussion of the possible implications of their survey for understanding-subjectivity and disagreements among experts and for understanding problems of communication between experts and laypersons. That discussion will not be repeated here except to note that the present results seem to reinforce the conclusion that toxicologists need to look anew at the strengths and limitations of their craft and need to play a 
greater role in interpreting the health implications of their data for the public. In doing this,

toxicologists should acknowledge the subjective elements, judgments, and assumptions

inherent in their analyses, as well as the degree of uncertainty in their conclusions.

\section{Acknowledgment}

This research was supported by a grant from the Department of National Health and Welfare

Canada to Decision Research. Additional support was provided by Grant No. SES-9122178

from the National Science Foundation to Decision Research.

\section{References}

1. N. Kraus, T. Malmfors, and P. Slovic, "Intuitive Toxicology: Expert and Lay Judgments of Chemical Risks," Risk Analysis 12, 215-232 (1992).

2. P. Rozin, L. Millman, and C. Nemeroff, "Operation of the Laws of Sympathetic Magic in Disgust and Other Domains," Journal of Personality and Social Psychology 50, 703-712 (1986).

3. D. Krewski, P. Slovic, S. Bartlett, J. Flynn, and C.K. Mertz, "Health-Risk Perception in Canada I: Rating Hazards, Sources of Information and Responsibility for Health Protection," Journal of Risk Analysis and Uncertainty (in press).

4. D. Krewski, P. Slovic, S. Bartlett, J. Flynn, and C.K. Mertz, "Health-Risk Perception in Canada II: Worldviews, Attitudes, and Opinions," Journal of Risk Analysis and Uncertainty (in press).

5. P. Slovic, J. Flynn, C. K. Mertz, and L. Mullican, Health-Risk Perception in Canada. Report No. 93-EHD-170 (Ottawa, Department of National Health and Welfare, 1993).

6. D. M. Buss, K. H. Craik, and K. M. Dake, "Contemporary Worldviews and Perception of the Technological System," in Risk Evaluation and Management, edited by V. T. Covello, J. Menkes, and J. Mumpower (New York, Plenum, 1986), pp. 93-130.

7. K. Dake, "Orienting Dispositions in the Perception of Risk: An Analysis of Contemporary Worldviews and Cultural Biases," Journal of Cross-Cultural Psychology 22, 61-82 (1991).

8. J. M. Jasper, Nuclear Politics: Energy and the State in the United States, Sweden, and France (Princeton, NJ, Princeton University Press, 1990).

9. J. Flynn, P. Slovic, and C. K. Mertz, "Gender, Race, and Perception of Environmental Health Risks," Risk Analysis 14, 1101-1108 (1994).

10. B. Ames, "Dietary Carcinogens and Anticarcinogens," Science 221, 1256-1264 (1983).

11. R. Carson, Silent Spring (New York, Houghton Mifflin, 1962). 


\section{Table 1}

Responses to Attitude and Opinion Statements: Category 1 General Opinions About Health Risks From Chemicals

\begin{tabular}{|c|c|c|c|c|c|c|}
\hline & . & $\begin{array}{l}\text { Strongly } \\
\text { disagree }\end{array}$ & Disagree & Agree & $\begin{array}{c}\text { Strongly } \\
\text { agree }\end{array}$ & $\begin{array}{c}\text { Don't know/ } \\
\text { no opinion }\end{array}$ \\
\hline $1 \mathrm{a}$. & $\begin{array}{l}\text { Use of chemicals has improved our } \\
\text { health more than it has harmed it } \\
(-.34)\end{array}$ & 4.7 & 9.3 & 49.3 & 33.3 & 3.3 \\
\hline $1 \mathrm{~b}$. & Most chemicals cause cancer $(.44)$ & 58.0 & 32.0 & 4.0 & 2.7 & 3.3 \\
\hline 1c. & $\begin{array}{l}\text { I try hard to avoid contact with } \\
\text { chemicals and chemical products in } \\
\text { my daily life }(.25)\end{array}$ & 16.7 & 49.3 & 27.3 & 4.7 & 2.0 \\
\hline
\end{tabular}

Note. Cell entries are percentages. Values in parentheses are correlations between responses to the statement and the risk-perception index. Correlations greater than .16 are significant at $p<.05$. Correlations greater than .21 are significant at $\mathrm{p}<.01$. 
Table 2

Responses to Attitude and Opinion Statements: Category 2 Trust in the Use of Animal Studies to Determine Human Health Risk

\begin{tabular}{clccccc}
\hline & $\begin{array}{c}\text { Strongly } \\
\text { disagree }\end{array}$ & Disagree & Agree & $\begin{array}{c}\text { Strongly } \\
\text { agree }\end{array}$ & $\begin{array}{c}\text { Don't know/ } \\
\text { no opinion }\end{array}$ \\
\hline 2a. $\begin{array}{l}\text { The way that an animal reacts to a } \\
\text { chemical is a reliable predictor of } \\
\text { how a human would react to it (-.12) }\end{array}$ & 4.0 & 26.0 & 56.7 & 9.3 & 4.0 \\
2b. $\begin{array}{l}\text { If a scientific study produces } \\
\text { evidence that a chemical causes } \\
\text { cancer in animals, then we can be } \\
\text { reasonably sure the chemical will } \\
\text { cause cancer in humans (.22) }\end{array}$ & 7.3 & 36.0 & 44.0 & 7.3 & 5.3 \\
\hline
\end{tabular}

Note. Cell entries are percentages. Values in parentheses are correlations between responses to the statement and the risk-perception index. Correlations greater than .16 are significant at $p<.05$. Correlations greater than .21 are significant at $\mathrm{p}<.01$. 
Table 3

Responses to Attitude and Opinion Statements: Category 3 Attitudes Toward Regulation

\begin{tabular}{|c|c|c|c|c|c|c|}
\hline & & $\begin{array}{l}\text { Strongly } \\
\text { disagree }\end{array}$ & Disagree & Agree & $\begin{array}{l}\text { Strongly } \\
\text { agree }\end{array}$ & $\begin{array}{c}\text { Don't know/ } \\
\text { no opinion }\end{array}$ \\
\hline $3 a$. & $\begin{array}{l}\text { I believe chemical risks are } \\
\text { adequately regulated }(-.29)\end{array}$ & 5.3 & 42.0 & 42.7 & 6.7 & 3.3 \\
\hline $3 b$. & $\begin{array}{l}\text { When there is a really serious health } \\
\text { problem, the government will } \\
\text { regulate it. Until they alert me about } \\
\text { a specific problem, I don't really. } \\
\text { have to worry }(-.30)\end{array}$ & 27.3 & 54.7 & 12.0 & 3.3 & 2.7 \\
\hline 3c. & $\begin{array}{l}\text { Because chemicals provide many } \\
\text { benefits to society, there should be } \\
\text { less regulation than there currently is } \\
(-.10)\end{array}$ & 28.0 & 64.0 & 5.3 & 0.7 & 2.0 \\
\hline $3 \mathrm{~d}$. & $\begin{array}{l}\text { A prescription drug that hasn't been } \\
\text { formally tested but has been used for } \\
20 \text { years is safer than a new } \\
\text { prescription drug that has been tested } \\
\text { and approved for use under the } \\
\text { present guidelines }(.00)\end{array}$ & 19.3 & 52.0 & 18.0 & 4.7 & 6.0 \\
\hline $3 e$. & $\begin{array}{l}\text { Government has no right to regulate } \\
\text { people's personal risk-taking } \\
\text { activities such as smoking, mountain } \\
\text { climbing, etc. (.04) }\end{array}$ & 12.0 & 59.3 & 20.0 & 5.3 & 3.3 \\
\hline
\end{tabular}

Note. Cell entries are percentages. Values in parentheses are correlations between responses to the statement and the risk-perception index. Correlations greater than .16 are significant at $\mathrm{p}<.05$. Correlations greater than .21 are significant at $\mathrm{p}<.01$. 


\section{Table 4}

Responses to Attitude and Opinion Statements: Category 4 Perceived Relationship Between Level of Exposure and Health Risk

\begin{tabular}{|c|c|c|c|c|c|c|}
\hline & & $\begin{array}{l}\text { Strongly } \\
\text { disagree }\end{array}$ & $\begin{array}{l}= \\
\text { Disagree }\end{array}$ & Agree & $\begin{array}{c}\text { Strongly } \\
\text { agree }\end{array}$ & $\begin{array}{l}\text { Don't know/ } \\
\text { no opinion }\end{array}$ \\
\hline $4 a$. & $\begin{array}{l}\text { If a person if exposed to a chemical } \\
\text { that can cause cancer then that } \\
\text { person will probably get cancer some } \\
\text { day }(.23)\end{array}$ & 34.7 & 49.3 & 7.3 & 3.3 & 5.3 \\
\hline $4 b$. & $\begin{array}{l}\text { Chemicals are either safe or } \\
\text { dangerous. There is really no in- } \\
\text { between }(.41)\end{array}$ & 62.7 & 31.3 & 4.7 & 0.0 & 1.3 \\
\hline 4c. & $\begin{array}{l}\text { If even a tiny amount of a substance } \\
\text { that can cause cancer were found in } \\
\text { my tap water, I wouldn't drink it } \\
(.34)\end{array}$ & 29.3 & 45.3 & 14.0 & $\begin{aligned} & 5.3 \\
\therefore & \end{aligned}$ & 6.0 \\
\hline
\end{tabular}

Note. Cell entries are percentages. Values in parentheses are correlations between responses to the statement and the risk-perception index. Correlations greater than .16 are significant at $p<.05$. Correlations greater than .21 are significant at $\mathrm{p}<.01$. 


\section{Table 5}

Responses to Attitude and Opinion Statements: Category 5 Other Questions Pertaining to Cancer

\begin{tabular}{llccccc}
\hline & & $\begin{array}{c}\text { Strongly } \\
\text { disagree }\end{array}$ & Disagree & Agree & $\begin{array}{c}\text { Strongly } \\
\text { agree }\end{array}$ & $\begin{array}{c}\text { Don't know/ } \\
\text { no opinion }\end{array}$ \\
\hline 5a. $\begin{array}{l}\text { Fruits and vegetables contain natural } \\
\text { substances that can cause cancer } \\
(-.07)\end{array}$ & 8.0 & 11.3 & 48.0 & 25.3 & 7.3 \\
5b. $\begin{array}{l}\text { People worry too much about getting } \\
\text { cancer from exposure to chemicals } \\
\text { (-.31) }\end{array}$ & 5.3 & 26.0 & 42.7 & 23.3 & 2.7 \\
5c. $\begin{array}{l}\text { The risk of getting cancer from } \\
\text { lifestyle factors such as smoking and } \\
\text { diet is much greater than the risk of } \\
\text { cancer from chemicals in the } \\
\text { environment }(-.23)\end{array}$ & 2.7 & 7.3 & 37.3 & 47.3 & 5.3 \\
\hline
\end{tabular}

Note. Cell entries are percentages. Values in parentheses are correlations between responses to the statement and the risk-perception index. Correlations greater than .16 are significant at $p<.05$. Correlations greater than .21 are significant at $\mathrm{p}<.01$. 


\section{Table 6}

Responses to Attitude and Opinion Statements: Category 6 Miscellaneous Questions

\begin{tabular}{llcccc}
\hline & $\begin{array}{c}\text { Strongly } \\
\text { disagree }\end{array}$ & Disagree & Agree & $\begin{array}{c}\text { Strongly } \\
\text { agree }\end{array}$ & $\begin{array}{c}\text { Don't know/ } \\
\text { no opinion }\end{array}$ \\
\hline 6a. $\begin{array}{l}\text { Natural chemicals are not as harmful } \\
\text { as man-made chemicals (.29) }\end{array}$ & 54.0 & 34.0 & 6.7 & 2.7 & 2.7 \\
6b. $\begin{array}{l}\text { There are serious environmental } \\
\text { health problems where I live (.25) }\end{array}$ & 27.3 & 45.3 & 20.0 & 3.3 & 4.0 \\
6c. $\begin{array}{l}\text { People can offset health risks from } \\
\text { pollution by improving their } \\
\text { individual lifestyle, such as } \\
\text { exercising and eating properly (-.12) }\end{array}$ & 6.0 & 26.0 & 37.3 & 25.3 & 5.3 \\
6d. $\begin{array}{l}\text { I believe that a risk-free environment } \\
\text { is an attainable goal in Canada (.27) }\end{array}$ & 41.3 & 36.7 & 14.7 & 5.3 & 2.0 \\
6e. $\begin{array}{l}\text { Canadians should be prepared to } \\
\text { accept some risks to their health in } \\
\text { order to strengthen the economy } \\
\text { (-.16) }\end{array}$ & 15.3 & 46.0 & 26.7 & 5.3 & 6.7 \\
6f. & & & & & \\
$\begin{array}{l}\text { Experts are able to make accurate } \\
\text { estimates of health risks from } \\
\text { chemicals in the environment (-.12) }\end{array}$ & 7.3 & 46.0 & 40.7 & 2.7 & 3.3 \\
\hline
\end{tabular}

Note. Cell entries are percentages. Values in parentheses are correlations between responses to the statement and the risk-perception index. Correlations greater than .16 are significant at $p<.05$. Correlations greater than .21 are significant at $\mathrm{p}<.01$. 
Table 7

Responses to Attitude and Opinion Statements: Category 7

Worldyiews

\begin{tabular}{|c|c|c|c|c|c|c|}
\hline & & $\begin{array}{l}\text { Strongly } \\
\text { disagree }\end{array}$ & Disagree & Agree & $\begin{array}{c}\text { Strongly } \\
\text { agree }\end{array}$ & $\begin{array}{c}\text { Don't know/ } \\
\text { no opinion }\end{array}$ \\
\hline $7 a$. & $\begin{array}{l}\text { I feel that I have very little control } \\
\text { over risks to my health (Fatalism) } \\
(.13)\end{array}$ & 13.3 & 52.0 & 26.0 & 5.3 & 3.3 \\
\hline $7 \mathrm{~b}$ & $\begin{array}{l}\text { Decisions about health risks should } \\
\text { be left to the experts (Hierarchy) } \\
(-.07)\end{array}$ & 13.3 & 52.0 & 26.0 & 5.3 & 3.3 \\
\hline $7 \mathrm{c}$ & $\begin{array}{l}\text { People in positions of authority tend } \\
\text { to abuse their power (Hierarchy) } \\
(.25)\end{array}$ & 2.0 & 40.7 & 38.0 & 7.3 & 12.0 \\
\hline $7 \mathrm{~d}$. & $\begin{array}{l}\text { In a fair system, people with more } \\
\text { ability should earn more } \\
\text { (Individualism) }(-.12)\end{array}$ & 0.7 & 10.7 & 63.3 & 19.3 & 6.0 \\
\hline $7 \mathrm{e}$. & $\begin{array}{l}\text { If people in this country were treated } \\
\text { more equally we would have fewer } \\
\text { problems (Egalitarianism) }(.20)\end{array}$ & 7.3 & 44.0 & 32.0 & 2.7 & 14.0 \\
\hline $7 \mathrm{f}$. & $\begin{array}{l}\text { A high technology society is } \\
\text { important for improving our health } \\
\text { and social well-being (Technological } \\
\text { Enthusiasm) }(-.14)\end{array}$ & 1.3 & 21.3 & 52.7 & 20.0 & 4.7 \\
\hline $7 \mathrm{~g}$. & $\begin{array}{l}\text { When a risk is very small, it is OK } \\
\text { for society to impose that risk on } \\
\text { individuals without their consent } \\
(-.20)\end{array}$ & 6.7 & 48.7 & 30.7 & 2.7 & 11.3 \\
\hline $7 \mathrm{~h}$. & $\begin{array}{l}\text { Continued economic growth is } \\
\text { necessary to improve our quality of } \\
\text { life }(-.08)\end{array}$ & 4.0 & 28.7 & 46.7 & 14.0 & 6.7 \\
\hline
\end{tabular}

Note. Cell entries are percentages. Values in parentheses are correlations between responses to the statement and the risk-perception index. Correlations greater than .16 are significant at $\mathrm{p}<.05$. Correlations greater than .21 are significant at $\mathrm{p}<.01$. 
Table 8

Distribution of the Risk Perception Index

\begin{tabular}{lcc}
\hline Index value & Frequency & Percent \\
\hline 1.0 to 1.5 & 2 & 1.3 \\
1.51 to 2.0 & 39 & 26.0 \\
2.01 to 2.5 & 69 & 46.0 \\
2.51 to 3.0 & 33 & 22.0 \\
3.01 to 3.5 & 6 & 4.0 \\
3.51 to 4.0 & 1 & 0.7 \\
\hline
\end{tabular}

Note. "Almost no risk" was coded as 1, "slight risk" as 2, "moderate risk" as 3 , and "high risk" as 4. 


\section{Table 9}

\section{Evaluations of Chemical B}

Q: Based on the information in the abstract you have read, what would you conclude about the level of evidence of carcinogenic activity of Chemical B for:

\begin{tabular}{|c|c|c|c|c|c|c|c|c|c|}
\hline & & & $\begin{array}{c}\begin{array}{c}\text { Clear } \\
\text { evidence }\end{array} \\
\end{array}$ & \multicolumn{2}{|c|}{$\begin{array}{c}\begin{array}{c}\text { Some } \\
\text { evidence }\end{array} \\
\end{array}$} & \multicolumn{2}{|c|}{$\begin{array}{c}\text { Equivocal } \\
\text { evidence }\end{array}$} & No evidence & $\begin{array}{c}\text { Inadequate } \\
\text { evidence }\end{array}$ \\
\hline B1: & Male rats & $\begin{array}{l}E^{a} \\
C^{b}\end{array}$ & $\begin{array}{r}8.8 \\
22.0\end{array}$ & \multicolumn{2}{|c|}{$\begin{array}{l}39.2^{*} \\
34.7^{*}\end{array}$} & \multicolumn{2}{|c|}{$\begin{array}{l}24.8 \\
26.7\end{array}$} & $\begin{array}{r}11.2 \\
7.3\end{array}$ & $\begin{array}{l}5.6 \\
4.0\end{array}$ \\
\hline B2: & Female rats & $\begin{array}{l}\mathrm{E} \\
\mathrm{C}\end{array}$ & $\begin{array}{l}12.8 \\
15.3\end{array}$ & \multicolumn{2}{|c|}{$\begin{array}{l}23.2 \\
23.3\end{array}$} & \multicolumn{2}{|c|}{$\begin{array}{l}25.6^{*} \\
26.7^{*}\end{array}$} & $\begin{array}{l}20.0 \\
20.7\end{array}$ & $\begin{array}{l}8.8 \\
8.0\end{array}$ \\
\hline B3: & Male mice & $\begin{array}{l}\mathrm{E} \\
\mathrm{C}\end{array}$ & $\begin{array}{l}16.8 \\
18.0\end{array}$ & \multicolumn{2}{|c|}{$\begin{array}{l}37.6 \\
40.7\end{array}$} & \multicolumn{2}{|c|}{$\begin{array}{l}26.4^{*} \\
26.0^{*}\end{array}$} & $\begin{array}{l}5.6 \\
5.3\end{array}$ & $\begin{array}{l}4.0 \\
3.3\end{array}$ \\
\hline B4: & Female mice & $\begin{array}{l}\mathrm{E} \\
\mathrm{C}\end{array}$ & $\begin{array}{l}52.8^{*} \\
56.0^{*}\end{array}$ & \multicolumn{2}{|c|}{$\begin{array}{l}25.6 \\
27.3\end{array}$} & \multicolumn{2}{|c|}{$\begin{array}{l}6.4 \\
6.7\end{array}$} & $\begin{array}{l}2.4 \\
0.7\end{array}$ & $\begin{array}{l}3.2 \\
2.7\end{array}$ \\
\hline \multicolumn{2}{|r|}{. } & & $\begin{array}{l}\text { Strongly } \\
\text { disagree }\end{array}$ & Disagree & \multicolumn{2}{|c|}{ Neither ${ }^{c}$} & Agree & $\begin{array}{c}\text { Strongly } \\
\text { agree }\end{array}$ & $\begin{array}{c}\text { Don't } \\
\text { know/ } \\
\text { no opinion }\end{array}$ \\
\hline B5: & $\begin{array}{l}\text { In general, animal studies } \\
\text { of the type done with } \\
\text { Chemical B will permit } \\
\text { one to make reliable } \\
\text { judgments of the } \\
\text { likelihood that the } \\
\text { chemical is carcinogenic } \\
\text { in humans }\end{array}$ & $\begin{array}{l}\mathrm{E} \\
\mathrm{C}\end{array}$ & $\begin{array}{l}3.2 \\
6.0\end{array}$ & $\begin{array}{l}23.2 \\
32.0\end{array}$ & $\begin{array}{r}26 \\
\mathrm{n} / \mathrm{a}\end{array}$ & & $\begin{array}{l}34.4 \\
47.3\end{array}$ & $\begin{array}{l}2.4 \\
3.3\end{array}$ & $\begin{array}{l}10.4 \\
11.3\end{array}$ \\
\hline B6: & $\begin{array}{l}\text { Based upon the data } \\
\text { presented above, a } \\
\text { concentration of } 1 \text { ppb of } \\
\text { Chemical B in indoor air } \\
\text { is acceptable }\end{array}$ & $\begin{array}{l}\mathrm{E} \\
\mathrm{C}\end{array}$ & $\begin{array}{l}4.0 \\
6.0\end{array}$ & $\begin{array}{l}15.2 \\
16.7\end{array}$ & $\begin{array}{r}18 \\
\mathrm{n} / \mathrm{a}\end{array}$ & & $\begin{array}{l}31.2 \\
42.7\end{array}$ & $\begin{array}{r}8.8 \\
10.0\end{array}$ & $\begin{array}{l}22.4 \\
24.7\end{array}$ \\
\hline & . & & $\begin{array}{l}\text { A probable } \\
\text { carcinogen } \\
\text { in humans }\end{array}$ & $\begin{array}{l}\text { A p } \\
\text { carc } \\
\text { in h }\end{array}$ & & $\begin{array}{r}\text { Pro } \\
\text { car } \\
\text { in } \\
\end{array}$ & $\begin{array}{l}\text { y not } \\
\text { genic } \\
\text { lans } \\
\end{array}$ & $\begin{array}{c}\text { Definitely } \\
\text { not } \\
\text { carcinogenic } \\
\text { in humans } \\
\end{array}$ & $\begin{array}{c}\text { The data are } \\
\text { not adequate } \\
\text { to make this } \\
\text { judgment }\end{array}$ \\
\hline B7: & Chemical B is... & $\begin{array}{l}\mathrm{E} \\
\mathrm{C}\end{array}$ & $\begin{array}{r}7.2 \\
14.0\end{array}$ & & & & & $\begin{array}{l}0.0 \\
0.0\end{array}$ & $\begin{array}{l}28.8 \\
28.7\end{array}$ \\
\hline
\end{tabular}

Note. Cell entries are percentages. Rows may not add to $100 \%$ because "don't know" and "no answer" responses are not always shown.

${ }^{\mathrm{a}} \mathrm{E}=$ European toxicologists.

${ }^{\mathrm{b}} \mathrm{C}=$ Canadian toxicologists.

"Slightly different response scales were used in the two samples. The Eurotox survey included a "neither agree nor disagree" category.

* The classification assigned by the panel of the National Toxicology Program is marked with an * for items B1 to B4. 
Table 10

Evaluations of Compound $E$

\begin{tabular}{|c|c|c|c|c|c|c|c|c|}
\hline & & & Very low & Low & Moderate & High & Very high & $\begin{array}{c}\text { Don't } \\
\text { know/ } \\
\text { no opinion } \\
\end{array}$ \\
\hline E1: & $\begin{array}{l}\text { The overall relative toxicity } \\
\text { of Compound } E \text { is: }\end{array}$ & $\begin{array}{l}E^{a} \\
C^{b}\end{array}$ & $\begin{array}{l}5.6 \\
5.3\end{array}$ & $\begin{array}{l}30.4 \\
44.0\end{array}$ & $\begin{array}{l}36.0 \\
30.7\end{array}$ & $\begin{array}{r}11.2 \\
6.7\end{array}$ & $\begin{array}{l}0.8 \\
0.7\end{array}$ & $\begin{array}{l}16.0 \\
12.7\end{array}$ \\
\hline $\mathrm{E} 2$ : & $\begin{array}{l}\text { The risk of using Compound } \\
\text { E as a rubber accelerant and } \\
\text { preservative is: }\end{array}$ & $\begin{array}{l}\mathrm{E} \\
\mathrm{C}\end{array}$ & $\begin{array}{l}2.4 \\
6.0\end{array}$ & $\begin{array}{l}36.0 \\
42.0\end{array}$ & $\begin{array}{l}23.2 \\
26.7\end{array}$ & $\begin{array}{r}20.0 \\
5.3\end{array}$ & $\begin{array}{l}1.6 \\
1.3\end{array}$ & $\begin{array}{l}16.8 \\
18.7\end{array}$ \\
\hline & & & $\begin{array}{l}\text { Strongly } \\
\text { disagree }\end{array}$ & Disagree & Agree & $\begin{array}{l}\text { Strongly } \\
\text { agree }\end{array}$ & & $\begin{array}{c}\text { Don't } \\
\text { know'/ } \\
\text { no opinion } \\
\end{array}$ \\
\hline E3: & $\begin{array}{l}\text { The presence of Compound } \\
\mathrm{E} \text { in rubber baby bottle } \\
\text { nipples is acceptable }\end{array}$ & $\begin{array}{l}\mathrm{E} \\
\mathrm{C}\end{array}$ & $\begin{array}{l}17.6 \\
10.0\end{array}$ & $\begin{array}{l}44.8 \\
38.7\end{array}$ & $\begin{array}{l}14.4 \\
21.3\end{array}$ & $\begin{array}{l}1.6 \\
3.3\end{array}$ & & $\begin{array}{l}21.6 \\
26.7\end{array}$ \\
\hline
\end{tabular}

Note. Cell entries are percentages.

${ }^{\mathrm{a}} \mathrm{E}=$ European toxicologists.

${ }^{\mathrm{b}} \mathrm{C}=$ Canadian toxicologists. 


\section{Figure Captions}

Figure 1. Health risks to the Canadian public (toxicologists survey). Source: 1993 Canadian Society of Toxicologists survey $(N=150)$.

Figure 2. Health risks to the Canadian public (public survey). Source: 1992 Health \& Welfare Canada survey $(N=1506)$.

Figure 3. Perceived health risks to Canadian public by gender: Difference between males and females. Percent difference is percent female moderate and high risk responses minus percent male moderate and high risk responses $(n=33$ females and 115 males). Source: 1993 Canadian Society of Toxicologists survey $(N=150)$.

Figure 4. Percent difference in agreement: Canadian public and toxicologists. Percent difference is percent of public's agree and strongly agree responses minus percent of toxicologists' strongly agree and agree responses. Source: 1992 Health \& Welfare Canada survey $(\mathrm{N}=1506)$ and 1993 Canadian Society of Toxicologists survey $(N=150)$. 